\title{
Phosphate and plankton dynamics during a drift experiment in the German Bight: simulation of phosphorus-related plankton production
}

\author{
Andreas Moll* \\ Institut für Meereskunde, Zentrum für Meeres- und Klimaforschung der Universität Hamburg, Troplowitzstr. 7, \\ D-22529 Hamburg, Germany
}

\begin{abstract}
As part of the German research project PRISMA, a drift experiment conducted in the German Bight in April 1991 showed that the diatom spring bloom was ending and a Phaeocystis bloom was beginning. Due to formation of Phaeocystis colonies, zooplankton biomass declined. Phosphate, nitrate and silicate were depleted and phosphate was below limiting values. The data are interpreted using a vertically resolved phosphorus-based primary production model. The model adequately explains the phosphate development and the amplitude and timing of the algal standing stock. It is inferred that primary production in this area is high, about $1.3 \mathrm{~g} \mathrm{C} \mathrm{m}^{-2} \mathrm{~d}^{-1}$, due to excellent production conditions at the end of April. The contributions of various processes are represented by the pathways of phosphorus in the upper $30 \mathrm{~m}$ of the water column. Phosphate uptake amounted to $4.8 \mathrm{mmol} \mathrm{m}^{-2}$ for the $6 \mathrm{~d}$ of the experiments. Sinking of phytoplankton plus diffusion and sinking of detritus to the bottom were the sources for bottom detritus $\left(0.6 \mathrm{mmol} \mathrm{\textrm {m } ^ { - 2 }}\right)$. The bottom detritus was mainly supplied by phytoplankton mortality $\left(0.3 \mathrm{mmol} \mathrm{m}^{-2}\right)$ due to ciliate grazing. Inorganic phosphate was supplied via benthic remineralization and upward diffusion $\left(0.9 \mathrm{mmol} \mathrm{m}^{-2}\right)$. The overall trend of phosphate and phytoplankton indicates that nearly the same water body was sampled over the course of the drift experiment. Due to the 6-hourly observations, interruptions due to advection in most of the measured parameters are visible. For the phytoplankton concentrations, the short-term and overall differences are shown by a comparison between the central drift station and 3 additional stations placed around the central station in a triangle and located 3 nautical miles away. The drift buoy moved in and out of the bloom area. The water column model neglects horizontal advection, so it would be better employed for mesocosm experiments. In the future fully 3 -dimensional models should be implemented.
\end{abstract}

KEY WORDS: North Sea - German Bight - Drift experiment - Plankton dynamics - Primary production model - Phosphorus budget

\section{INTRODUCTION}

The phase transformations between dissolved nutrients and particulate matter are important for an understanding of the trophic web in the German Bight in general, and thus of the contaminant transfer in particular. The surveys and the drift experiment conducted within the framework of the German research project PRISMA were mainly designed to obtain relevant transfer rates of contaminants, whereas no measurements of algal production rates and nutrient processes

·E-mail: moll@ifm.uni-hamburg.de were made. Therefore, an attempt is made here to explain the phytoplankton and phosphate development at the central drift station by means of a 1-dimensional primary production model (Radach \& Moll 1993), and hence to obtain estimates of the contribution made by phosphorus-related processes to the dynamics of the bloom.

The primary production model has been validated for annual cycles in the central North Sea (Radach \& Moll 1993) and for calculating the main processes of the pelagic phosphorus cycle. In a case study in summer 1986 (2 May to 13 June) the model system provided values for phytoplankton biomass and primary 
production in the same range as those observed close to the centre of the star-shaped surveys in the project ZISCH (Moll \& Radach 1994).

Comparison of observations from the PRISMA drift experiment with the simulation is another step in the validation of the primary production model. The advantage of the simulation consists in its potential to explain dynamic structures and aid interpretation of the data. The results are discussed in the framework of the influence of advection.

\section{MATERIAL AND METHODS}

Sampling and data analysis. The sampling techniques, nutrient analysis and plankton analysis are given in detail in Raabe et al. (1997 in this volume); here the methods are reported briefly.

Nutrient analyses were carried out on water samples taken with a rosette sampler at $0,5,10,20$ and $30 \mathrm{~m}$ depth and above the bottom. These were filtered over glass fibre filters (Whatman $\mathrm{GF} / \mathrm{C}$ ) at low pressure (<0.2 bar). The phosphate concentration was measured with a Technicon AutoAnalyser System II.

For phytoplankton analysis, water samples from the rosette were preserved in a $1 \%$ solution of formalin and phytoplankton composition was determined. For calculation of biomass, a geometrical body was assigned to each phytoplankton species and the necessary parameters for determining volume and surface area were measured and converted to carbon. Due to the sampling procedure used, the actual biomass might have been higher, because picophytoplankton was not sampled (for a discussion see Raabe et al. 1997).

Zooplankton samples were collected with a WP-2 net (mesh size $200 \mu \mathrm{m}$ ) from near the bottom up to the surface. This material was preserved and representative parts of the samples were sorted for taxonomic analysis in the laboratory. The numbers of meso- and macrozooplankton of different taxa were counted and converted into carbon biomass.

Primary production model. The model consists of 3 mass conservation equations (phytoplankton, phosphate and bottom detritus), and is described in detail by Radach \& Moll (1993) (see Fig. 1). The model incorporates formulations of primary production and remineralization mechanisms within the mixed layer, in the lower layer and at the bottom.

Primary producers sink, die, and are grazed by zooplankton. In general, grazed phytoplankton is subdivided into 3 portions: the first is used in zooplankton growth, the second is lost as fecal pellets, and the third is excreted by zooplankton as dissolved metabolites replenishing the phosphate pool. A proportion of the material contributing to growth is assumed to be lost immediately, representing zooplankton death. Portions of both fecal pellets and the excreted dissolved material are immediately regenerated. It is assumed that most of the sinking dead material is collected in a detritus pool at the bottom. Only a small amount of detritus remains suspended in the water column.

The effect of the microbial food web is parameterized by converting a portion of detrital material immediately into regenerated phosphate within the water column. The complex process of remineralization is parameterized by assuming a fixed net remineralization rate. The 2 pathways for nutrient regeneration, the pelagic and the benthic, are controlled by physical processes.

The bloom during the drift experiment was dominated by the marine haptophyte alga Phaeocystis. There is some taxonomic confusion due to the use of the term 'P. pouchetii' in the literature to refer to what is probably more than 1 Phaeocystis species (Bätje \& Michaelis 1986). In the recent literature a distinction is made between the northern, arctic $P$. pouchetii and the southern, coastal-water $P$. globosa (Jahnke 1989). The mean features of a Phaeocystis bloom and the related primary production (Lancelot et al. 1991) are simulated in the phosphorus-based water column model, which is sophisticated in its representation of physical environmental conditions.

The model constants and conversion factors are taken from Radach \& Moll (1993). Three parameters were changed in order to adapt the model to Phaeocystis globosa. For the optimum growth rate a value of $3.0 \mathrm{~d}^{-1}$ from Lancelot \& Mahot (1987) was used. The optimum light intensity was $5 \mathrm{~W} \mathrm{~m}^{-2}$ (Veldhuis et al. 1987, Jahnke 1989), and the basic respiration rate was set at 5\% after Lancelot et al. $(1990,1991)$.

\section{OBSERVATIONAL BACKGROUND}

A survey of the German Bight (17 to 20 April 1991) provided the observational background at the beginning of the drift experiment. The hydrographical situation during April 1991 was simulated with a 3-dimensional hydro-thermodynamic model (Schrum et al. 1997 in this volume) that resolved the complex frontal system among the different water bodies and provided the necessary forcing data for the primary production simulation.

Meteorological and hydrographical situation. During the first phase of the drift experiment (23 to 26 April) the meteorological situation changed from westerly winds to easterly winds, whereupon a corresponding anticyclonic oceanographic circulation developed. The wind-induced surface transport caused a strong vertical velocity shear. This shear led to a coinciding of 


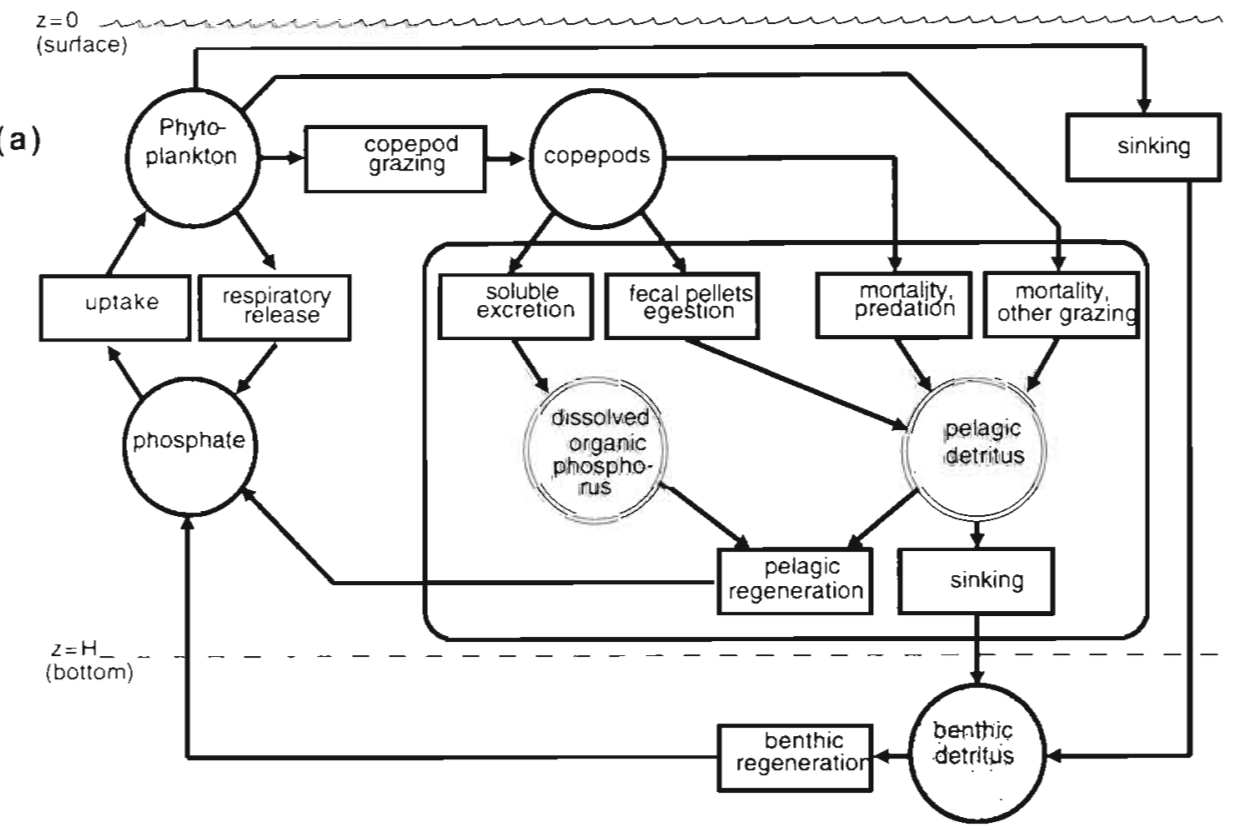

Fig. 1 Diagram of the water column model showing interactions and phosphorus budget terms. (a) Simplified phosphorus cycle of the biological-upper-layer model showing prognostic variables (shaded circles), diagnostic variables (white circles), indirectly modelled variables (double circles) and processes (boxes), after Radach \& Moll (1993). (b) Pathways of phosphorus through the model system in the upper $30 \mathrm{~m}$ for the duration of the drift exper-

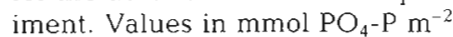
(6 d)

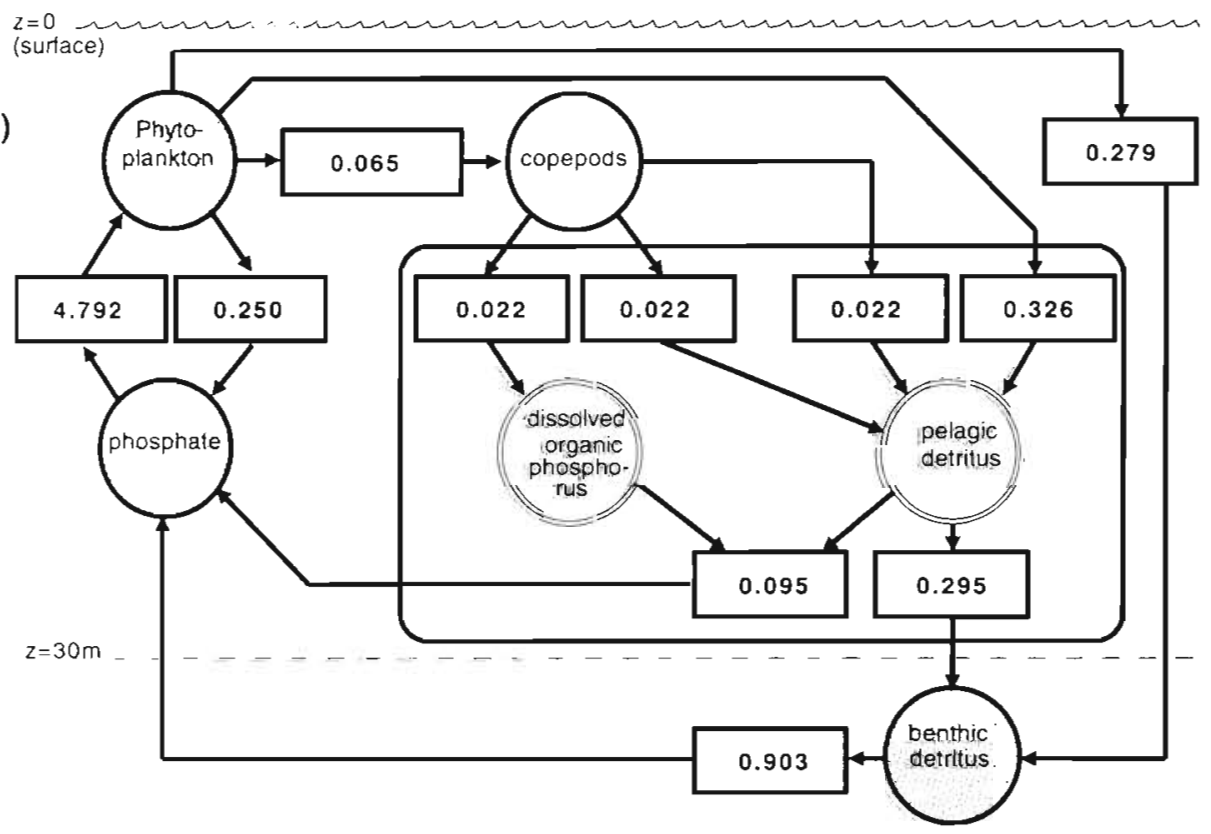

water masses of different origin in the drift experiment area. In the upper part of the water column, coastal freshwater spread out over the German Bight, while an influx of saline North Sea water near the bottom occurred (Fig. 2). The increased wind velocities during the night of April 26 caused an increase of near-surface transport and an extension of the stratified region. The second phase of the drift experiment (27 to 29 April) was marked by the deflection of the wind vector to northerly directions, with a change in the circulation.
The strong vertical shear of the transport field diminished and surface and deep transport moved in the

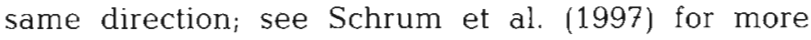
details.

Horizontal distribution of phosphate, phyto- and zooplankton. The isopleths of the horizontal distribution of phosphate expressed no significant front (Fig. 2 in Raabe et al. 1997). Maximum phosphate concentrations of more than $0.2 \mu \mathrm{mol} \mathrm{l}^{-1}$ were found close to the mouths of the Elbe and Weser. The concentrations 


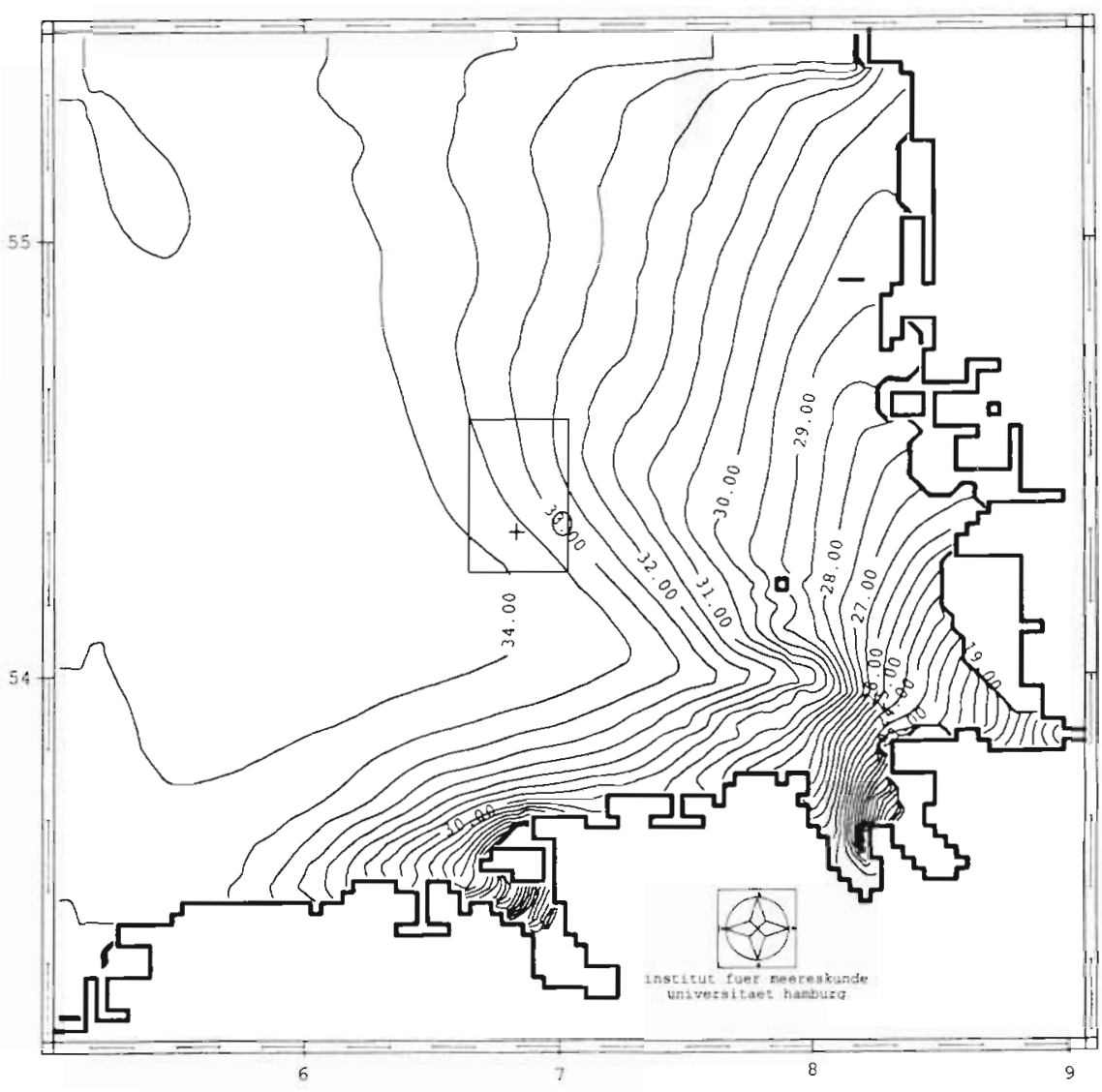

Fig. 2. Horizontal salinity distribution in April 1991 in psu. Rectangle marks the drift area. After Schrum et al. (1997)
The whole drift experiment took place in an area where Phaeocystis globosa dominated, forming at least $95 \%$ of the phytoplankton biomass. Diatoms (e.g. Coscinodiscus wailesii, Odontella sinensis, Thalassiosira punctigera) and dinoflagellates (e.g. Ceratium and Protoperidinium species) were only occasionally found.

Mesozooplankton biomasses in the German Bight were dominated by copepods at that time. Mainly, small copepods such as Pseudocalanus elongatus, Temora longicornis, Centropages hamatus and Acartia clausi were found, with numbers generally increasing from east to west (Fig. 12 in Raabe et al. 1997). Species of the open North Sea, such as the large calanoid copepod Calanus as well as the small cyclopoid Oithona, occurred mainly in the offshore regions of the German Bight. Numbers as well as biomasses of the copepods generally increased from southeast to northwest. Areas of high total zooplankton biomasses were found at the northwest boundary, near the Elbe estuary and near the island of Sylt.

decreased from south to north. Minima of less than

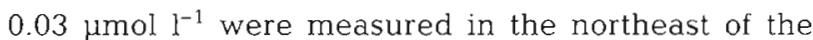
investigated area off the island of Sylt. Off the coast the concentrations increased from 0.05 to $0.2 \mu \mathrm{mol} \mathrm{l^{-1 }}$ in the northeast.

The highest phytoplankton density during the investigation period was found in the southeastern part of the German Bight, with carbon concentrations over $600 \mu \mathrm{g} \mathrm{C} \mathrm{I}^{-1}$. Off the North Frisian and East Frisian coast values between 50 and $200 \mu \mathrm{g} \mathrm{C} \mathrm{l}^{-1}$ were measured, in contrast to the outer German Bight, where phytoplankton biomass strongly decreased to $5 \mu \mathrm{g} \mathrm{C}$ $\mathrm{l}^{-1}$ (Fig. 8 in Raabe et al. 1997).

The phytoplankton in the eastern part of the area was dominated by diatoms, with a maximum biomass of $400 \mu \mathrm{g} \mathrm{Cl}^{-1}$ around Helgoland. In the southwest and in parts of the outer German Bight the prymnesiophycean Phaeocystis globosa dominated the phytoplankton. During the investigation period a maximum biomass of $300 \mu \mathrm{g} \mathrm{C}^{-1}$ was recorded. The final sampling of the station grid at the end of April showed that this species had spread towards the northeast of the German Bight.
Coastal maxima were mainly represented by bottom invertebrate larvae and hydromedusae.

\section{RESULTS OF THE SIMULATION}

The drift experiment started on 23 April at 18:00 h ent- and plankton-related observations are shown in detail by Raabe et al. (1997); here the results of the simulation are presented. For comparison to the other articles in this volume concentrations are reported for $1.0 \mathrm{~m}$ water depth.

\section{Development of physical parameters}

The model of Schrum et al. (1997) provided the necessary forcing data for the primary production simulation. The results regarding the hydrographical situation during the $6 \mathrm{~d}$ drift are part of a hindcast simulation for January to April 1991. Temperature and turbulent diffusion coefficients along the drift track UTC and continued over $144 \mathrm{~h}$. The results of the nutri- 

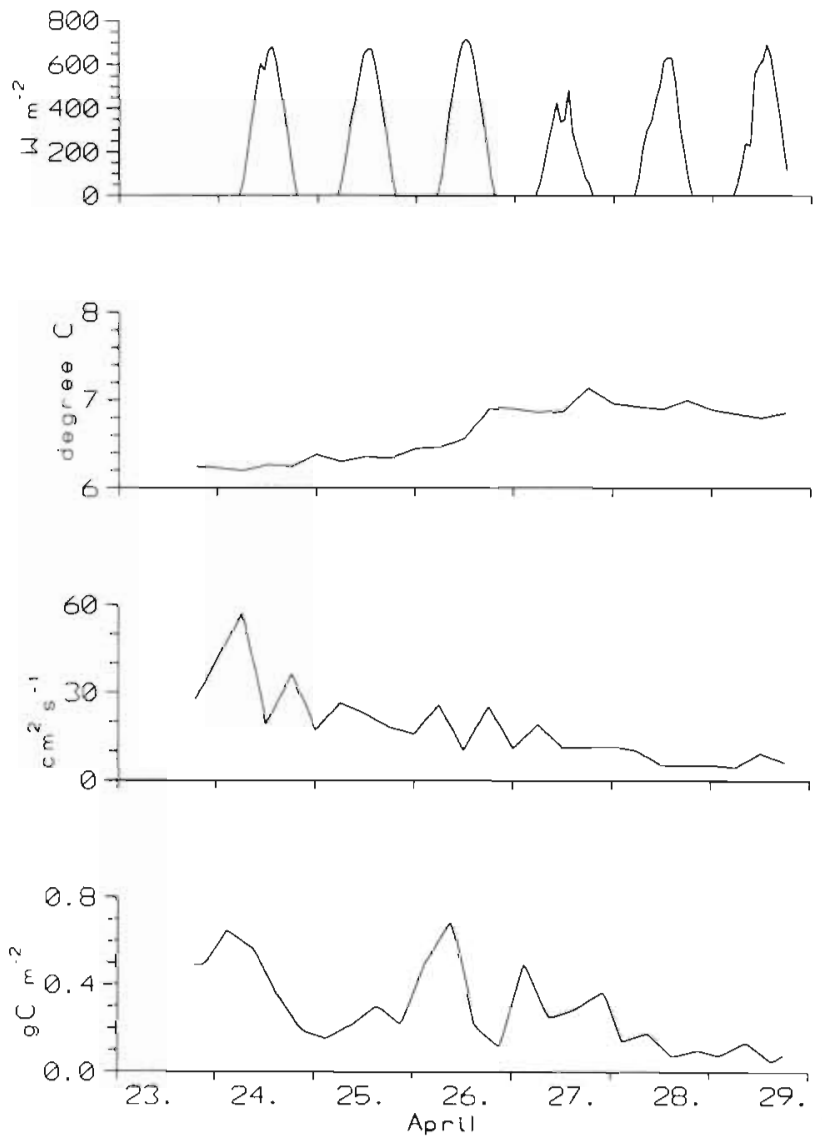

Fig. 3. Time series of forcing parameters for the water column model: (a) calculated solar radiation; (b) simulated sea surface temperature and (c) simulated turbulent diffusion coefficlents, after Schrum et al. (1997); and (d) observed zooplankton biomass, after Raabe et al. (1997)

were taken from the simulation as the physical forcing for the water-column-model runs.

Global radiation at the sea surface (Fig. 3) was calculated using measured cloudiness in octas. Daily radiation increased during the first $3 \mathrm{~d}$. On 27 April radiation was strikingly low, increasing thereafter.

Sea surface temperature (Fig. 3) rose from $6.2^{\circ} \mathrm{C}$ at the beginning of the experiment to nearly $7^{\circ} \mathrm{C}$ over the $6 \mathrm{~d}$, and a weak thermocline at about $7 \mathrm{~m}$ water depth developed from 25 April onwards. Salinity (not shown) was quite constant during the first $3 \mathrm{~d}$ and decreased after 26 April from 34.10 to 34.00 psu until the end of the experiment (see Schrum et al. 1997).

At the beginning of the experiment a homogeneous vertical structure with turbulent diffusion coefficients above $30 \mathrm{~cm}^{2} \mathrm{~s}^{-1}$ was found (Fig. 3). Due to a mixed surface layer from noon on 24 April onwards, the diffusion decreased. The diffusion in the upper layer continued decreasing until the end of the experiment, and a 3-layer structure with an additional tidally generated turbulent bottom layer became established. After 27 April mean turbulent diffusion coefficients were on the order of $10 \mathrm{~cm}^{2} \mathrm{~s}^{-1}$.

\section{Development of phosphate and phyto- and zooplankton}

During the first $3 \mathrm{~d}$ of the drift experiment the phosphate concentrations remained at a relatively high level of $0.12 \mathrm{~mol} \mathrm{I}^{-1}$ at the central station (Fig. 4). Phosphate decreased slightly from 0.14 to $0.1 \mu^{m o l} \mathrm{l}^{-1}$. In the night from 25 to 26 April the concentration started to decrease. During the daytime of 26 April the time series at the outer drifting stations showed also a shift in concentrations (Raabe et al. 1997). At the central station phosphate decreased from 0.12 to $0.07 \mu \mathrm{mol}$ $1^{-1}$. By the end of the experiment the concentrations had decreased to values below $0.06 \mu \mathrm{mol} \mathrm{l}^{-1}$. The observations showed occasional outliers with values below $0.02 \mu \mathrm{mol} \mathrm{I}^{-1}$, and the 6 -hourly values were highly variable.

Before 26 April only low biomasses were measured except for 1 sampling with clearly higher values (Fig. 5). Overnight on 26 April the phytoplankton biomass rose to $160 \mu \mathrm{C} \mathrm{Cl}^{-1}$ and fell again at the subsequent samplings. During 27 April the concentrations increased again to values around $120 \mathrm{\mu g} \mathrm{Cl}^{-1}$. During the last $2 \mathrm{~d}$, concentrations reached maximum values of $300 \mu \mathrm{g} \mathrm{Cl}^{-1}$. After that the values were lower again.

The copepod biomass showed generally low values below $12 \mu \mathrm{g} \mathrm{Cl}^{-1}$, or $0.7 \mathrm{~g} \mathrm{C} \mathrm{m}^{-2}$ in the water column

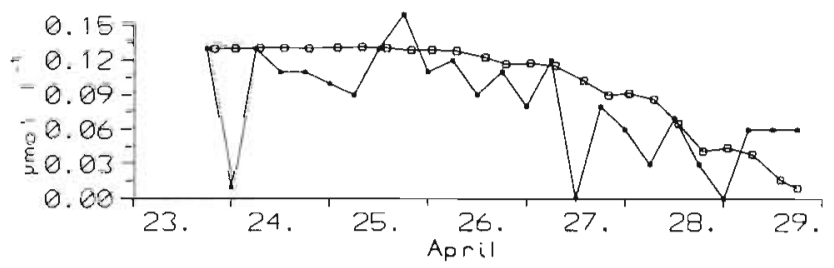

Fig. 4. Time series of observed (Raabe et al. 1997) phosphate (.) and simulated phosphate (o) in $\mu \mathrm{mol} \mathrm{PO}_{4}-\mathrm{P} \mathrm{I}^{-1}$ at the drift position at $10 \mathrm{~m}$ depth

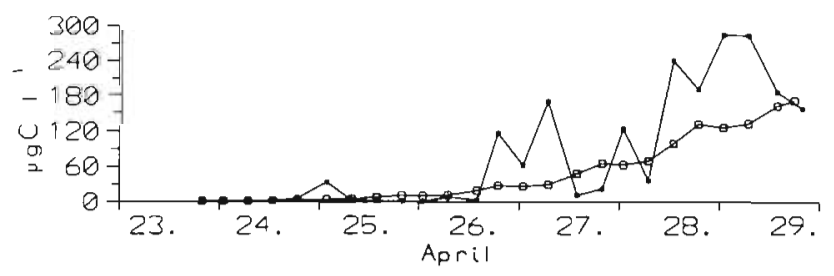

Fig. 5. Time series of observed (Raabe et al. 1997) phytoplankton concentration $(\cdot)$ and simulated phytoplankton concentration (a) in $\mu \mathrm{g} \mathrm{C}^{-1}$ at the drift position at $10 \mathrm{~m}$ depth 
(Fig 3). During the drift experiment the copepod biomass varied between 50 and $90 \%$ of the total zooplankton biomass. The zooplankton biomass decreased continuously during the drift and reached values below $0.1 \mathrm{~g} \mathrm{C} \mathrm{m}^{-2}$ or $1.8 \mu \mathrm{g} \mathrm{C} \mathrm{I}^{-1}$.

\section{Model validation}

Vertical profiles of phytoplankton and phosphate were simulated with the 1-dimensional primary production model.

In Fig. 5 the simulated phytoplankton concentration at $10 \mathrm{~m}$ depth is presented together with the observed concentrations. The simulated phytoplankton concentration increased due to primary production during daytime and decreased due to respiration and other loss terms at night. The overall trend of the observed phytoplankton development is well represented by the simulation, but the observations are much more variable. The 6-hourly changes are dramatic, with highest values at night (Fig. 5). The model results are not able to follow the variable 6 -hourly observations.

The simulated phosphate concentration is shown in Fig. 4. At the beginning of the simulation period the concentration is quite constant, but after 26 April the concentration decreases due to phytoplankton growth, when environmental conditions of vertical turbulent diffusion (Fig. 3) enhance a bloom event. The daily cycles of phosphate uptake continue to the end of the experiment, reflecting the primary production and the growing phytoplankton stock.

For validation, the observed and simulated concentrations at $10 \mathrm{~m}$ depth were compared. The simulated phytoplankton concentration agreed with the observations up to 27 April; afterwards, the measurements were more variable than the simulations, and the simulated values reached only the lower range of observed values (Fig. 5). The simulated phosphate concentrations were in good agreement with the observations for the first $5 \mathrm{~d}$ (Fig. 4). After 28 April the observations and simulated values diverged. The phosphate observations were highly variable over the full period of the drift experiment.

\section{Calculated primary production processes}

The phytoplankton processes simulated were primary production, respiration, mortality and grazing by copepods (Fig. 1). Results of the simulated vertical profiles are reported briefly. Production occurred all the way down to the bottom until 27 April; afterwards, production occurred mainly between 5 and $20 \mathrm{~m}$ water depth. Respiration, mortality and grazing were less important and the change in the vertical structure of these processes over time was simple.

The processes involving phosphate were uptake, release in the dark, remineralization in the water and excretion by copepods (Fig. 1). The dominant uptake process corresponded to the primary production process. The release of phosphate in the dark due to exudation increased when the amount of the phytoplankton stocks increased. Remineralization and excretion of phosphate were negligible in the water column.

Fig. 1 shows the pathways of phosphorus in the model. The phosphorus fluxes during the drift experiment were derived from the simulation and are calculated for the upper $30 \mathrm{~m}$ of the water column. Phosphate uptake due to production during daytime amounts to $4.8 \mathrm{mmol} \mathrm{m}^{-2}$ for the $6 \mathrm{~d}$ drift period. Sinking of phytoplankton plus diffusion $\left(0.28 \mathrm{mmol} \mathrm{m} \mathrm{m}^{-2}\right)$ and sinking of detritus out of the water column to the bottom $\left(0.3 \mathrm{mmol} \mathrm{m}^{-2}\right)$ are the sources of bottom detritus. The bottom detritus is mainly supplied by phytoplankton mortality $\left(0.3 \mathrm{mmol} \mathrm{m}^{-2}\right)$ due to ciliate grazing. Nutrient supply functions mainly via benthic remineralization and upward diffusion $\left(0.9 \mathrm{mmol} \mathrm{m} \mathrm{m}^{-2}\right)$ and, in smaller amounts, by exudation $10.25 \mathrm{mmol}$

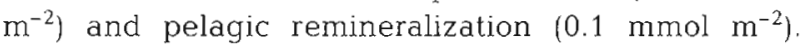
Excretion and fecal pellet production by copepods are negligible during the Phaeocystis bloom (both $0.02 \mathrm{mmol} \mathrm{m}^{-2}$ ).

\section{DISCUSSION}

\section{Main features}

The survey in the German Bight in April 1991 showed a typical situation for the nutrient and plankton distribution. Within the areas of high phytoplankton standing stock, concentrations of dissolved inorganic phosphate had dropped to very low concentrations, whereas the water was still rich in inorganic nitrogen (Raabe et al. 1997). Growth conditions for Phaeocystis seem to be most favourable after breakdown of a diatom bloom when the silicate reserves have been exhausted and phosphate concentrations are relatively low, as Bauerfeind et al. (1990) have shown. Another characteristic observed is the release of large amounts of dissolved organic substances, which cause extensive sea foam (Bätje \& Michaelis 1986).

The meteorological situation in the German Bight, with weak easterly winds, induced a circulation system with near-surface transport and bottom transport occurring in opposite directions and favourable growth conditions due to stratification (Schrum et al. 1997). 


\section{Limiting nutrient}

During the drift experiment nitrate and phosphate concentrations ran mainly parallel (Raabe et al. 1997), but phosphate concentrations decreased to limiting values. The N:P ratio increased from 30 at the beginning of the experiment to 40 on 30 April. In the German Bight phosphate appears to be the limiting nutrient for long periods of the year. Radach et al. (1990) showed this for the Helgoland data and Bauerfeind et al. (1990) for the spring phytoplankton bloom in the German Bight, where ratios of N:P were greater than 50. Therefore, phosphate seemed to be the appropriate nutrient to choose to study primary production processes with the model.

\section{Advection}

The observations reflect the full system's dynamics, including the advective and diffusive lateral transports. One can see the interruption due to advection in many of the measurements during the drift experiment between 26 and 27 April (König \& Schrum 1997, Raabe et al. 1997 , both in this volume).

Let us consider here the structure in space given by the phytoplankton concentrations at $10 \mathrm{~m}$ depth at the 3 corners of the drift array (Fig. 6). At the northeast and southern stations phytoplankton concentrations increased during the first $2 \mathrm{~d}$, but no increase was observed at the northwest station. The first increase in phytoplankton at the southern station lagged behind that at the northeast station by half a day. By looking at the development of the biomass at the peripheral stations it may be seen that higher biomasses at the northwest and northeast stations were not measured before 28 April. Only at the southern station did values between 150 and $300 \mu \mathrm{g} \mathrm{C} 1^{-1}$ appear earlier, although the development was very irregular. The time lag for the phytoplankton bloom is greater in the northwest corner, the most offshore station. The onset of the bloom, represented by increasing phytoplankton concentrations, is shifted earlier from north to south.

During the drift experiment, phosphate and phytoplankton observations were highly variable. The overall trend is represented by the simulation, but without the short-term (6-hourly) variations. Thus, a possible explanation is that the drifting buoy moved back and forth during the sampled track time and moved into another water mass after 26 April. This assumption is supported by the results of König \& Schrum (1997), who calculated the distance between the real position of the drift buoy and the position simulated by the model. From 25 to 27 April this distance reached its maximum. A significant decrease in the salinity values
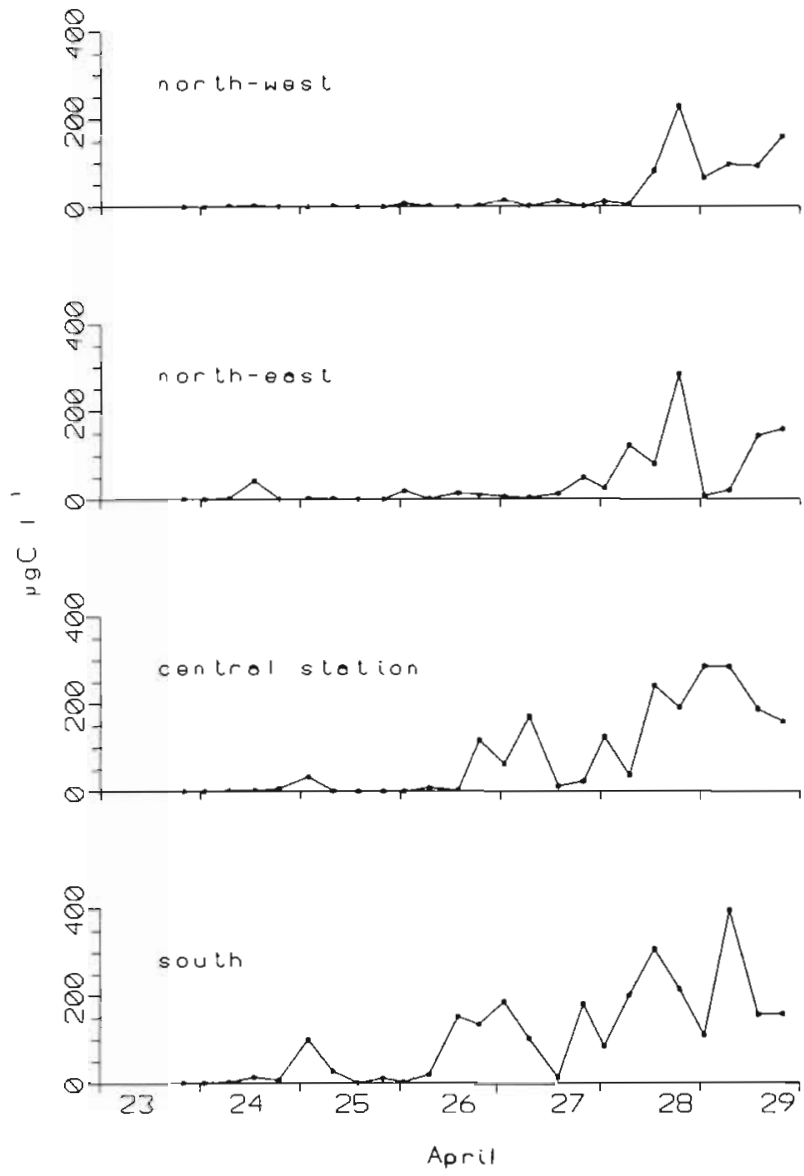

Fig. 6. Time series of observed (Raabe et al. 1997) phytoplankton concentrations ( $\mu \mathrm{g} \mathrm{C} \mathrm{C}^{-1}$ ) during the drift at the central station and the surrounding stations located 3 nautical miles northwest, northeast and south of the central drifter. Observations at $10 \mathrm{~m}$ depth

supports the idea that the drifter moved into a different water body (König \& Schrum 1997). Salinity showed the same 6-hourly variability as phosphate.

As a consequence, the observed overall changes in phosphate (Fig. 4) and phytoplankton (Fig. 5) were mainly due to turnover processes caused by a strongly developed phytoplankton bloom, but with short-term variations over $6 \mathrm{~h}$ due to sampling of different water bodies occupied by the drifting buoy (Fig. 6). Thus, the drift buoy was not suitable for marking a 'selected water body' (König \& Schrum 1997), but it was possible to study the development of a bloom event and to use a model to calculate the contributions of various processes.

\section{Phosphorus budget}

The primary production calculated from the water column model was $7.9 \mathrm{~g} \mathrm{C} \mathrm{m}^{-2}$ for $6 \mathrm{~d}$ or a mean of 
$1.3 \mathrm{~g} \mathrm{C} \mathrm{m}^{-2} \mathrm{~d}^{-1}$. The most productive day reached $2.9 \mathrm{~g} \mathrm{C} \mathrm{m}^{-2} \mathrm{~d}^{-1}$ This is in agreement with incubation experiments of Veldhuis et al. (1986) for Dutch coastal waters reporting production values between 1 and $4.8 \mathrm{~g} \mathrm{C} \mathrm{m}^{-2} \mathrm{~d}^{-1}$. The mean value for the spring bloom was $1.44 \mathrm{~g} \mathrm{C} \mathrm{m}^{-2} \mathrm{~d}^{-1}$ based on $8 \mathrm{~h}$ incubation observations, which matches the simulated flux in the present study

Benthic remineralization was $0.9 \mathrm{mmol} \mathrm{m}^{-2}$ for the $6 \mathrm{~d}$ or $0.15 \mathrm{mmol} \mathrm{m} \mathrm{m}^{-2} \mathrm{~d}^{-1}$. Slomp et al. (1993) investigated the sediment-water exchange rates of phosphate by weekly additions of Phaeocystis cells which sedimented to the bottom. The remineralization rates for these boxcosm experiments range between 0.1 and $0.3 \mathrm{mmol} \mathrm{m}^{-2} \mathrm{~d}^{-1}$ and are thus in agreement with the simulated flux.

Sedimentation of organic particles accounted for $0.12 \%$ of the primary production during the drift experiment. Data by Cadee (1986) indicated that daily sedimentation amounted to nearly $1 \%$ of the daily primary production. These observations were made during a 1 mo drift experiment in the Fladen Ground area. Thus, total sedimentation might have been stronger due to the longer period of the experiment.

The zooplankton biomass minimum in the drift area is correlated to high abundances of Phaeocystis, because Phaeocystis is not a suitable food source for copepods, but literature data on Phaeocystis grazing remains controversial (Lancelot 1990). Larger copepods like Calanus species were mainly in the offshore regions. Significant grazing has been reported for tintinnids during the spring bloom in Dutch coastal waters, where these protozoa grazed on the single-cell stage of the colony-forming Phaeocystis (Admiraal \& Venekamp 1986). Steiff (1988) indicates that microzooplankton formed about $10 \%$ of the phytoplankton stock during April-May 1985 at Helgoland. In the water column model, the importance of tintinnid and ciliate grazing on Phaeocystis is represented by high mortality rates compared to copepod grazing (Fig. 1).

\section{Success of the drift experiment}

The model results showed that it was possible to simulate the overall trend of the observations and to calculate plausible values for the contributions of different processes to the production cycle during the drift experiment for the observed Phaeocystis bloom. With the advection problem in mind, it would be better to test the water column model by mesocosm experiments to reduce external influences and to measure important processes. Within this framework, observed contributions of different processes could be used to validate the chemical-biological process parameteriza- tions. To overcome the advection problem during the drift experiment, a 3-dimensional model should be used, e.g. the model of Moll (1997).

Acknowledgements. This work was supported by the Bundesministerium für Forschung und Technologie under the PRISMA project (Grant 03F0558A1). The author would like to acknowledge his debts for the data and for comments on previous versions of the manuscript to $T$. Raabe (phosphate), C.-D. Dürselen (phytoplankton), M. Krause (zooplankton), $\mathrm{S}$. Beddig and J. Sündermann (comments)

\section{LITERATURE CITED}

Admiraal W, Venekamp LAH (1986) Significance of tintinnid grazing during blooms of Phaeocystis pouchetii (Haptophyceae) in Dutch coastal waters. Neth J Sea Res 20: $61-66$

Bätje M, Michaelis H (1986) Phaeocystis pouchetii blooms in the East Frisian coastal waters (German Bight, North Sea). Mar Biol 93:21-27

Bauerfeind E, Hickel W, Niermann U, Westernhagen $\mathrm{Hv}$ (1990) Phytoplankton biomass and potential nutrient limitation of phytoplankton development in the south-eastern North Sea in spring 1985 and 1986. Neth J Sea Res 25 $(1 / 2): 131-142$

Cadee GC (1986) Organic carbon in the water column and its sedimentation, Fladen Ground (North Sea), May 1983. Neth J Sea Res 20:347-358

Jahnke J (1989) The light and temperature dependence of growth rate and elemental composition of Phaeocystis giobosa Scherffel and P. pouchetii (Har.) Lagerh. in batch cultures. Neth J Sea Res 23:15-21

König P, Schrum C (1997) Hydrographic observations and model results from a PRISMA drift experiment. Mar Ecol Prog Ser 156:255-261

Lancelot C (1990) Phaeocystis blooms in the continental coastal area of the channel and the North Sea. In: Lancelot C. Billen G, Barth H (eds) Eutrophication and algal blooms in North Sea coastal zones, the Baltic and adjacent areas. Wat Pollut Res Rep 12:27-54

Lancelot C, Billen G, Barth H (eds) (1990) Eutrophication and algal blooms in North Sea coastal zones, the Baltic and adjacent areas: prediction and assessment of preventive actions. Wat Pollut Res Rep 12

Lancelot C, Billen G, Barth H (1991) The dynamics of Phaeocystis blooms in nutrient enriched coastal zones. Wat Pollut Res Rep 23:1-106

Lancelot C. Mahot S (1987) Dynamics of a Phaeocystis-dominated spring bloom in Belgian coastal waters. I. Phytoplanktonic activities and related parameters. Mar Ecol Prog Ser 37:239-248

Moll A (1997) Modeling primary production in the North Sea Oceanography 10:24-26

Moll A, Radach G (1994) Phytoplankton modelling in the central North Sea during ZISCH 1986. In: Sündermann J (ed) Circulation and contaminant fluxes in the North Sea Springer-Verlag, Berlin, p 403-433

Raabe TH, Brockmann UH, Dürselen CD, Krause M, Rick HJ (1997) Nutrient and plankton dynamics during a spring drift experiment in the German Bight. Mar Ecol Prog Ser 156:275-288

Radach G, Berg J, Hagmeier E (1990) Long-term changes of the annual cycles of meteorological, hydrographic, nutrient and phytoplankton time series at Helgoland and at LV 
ELBE 1 in the German Bight. Cont Shelf Res 10:305-328 Radach $G$, Moll A (1993) Estimation of the variability of production by simulating annual cycles of phytoplankton in the central North Sea. Prog Oceanogr 31:339-419

Schrum C, König P, Michaelsen K, Niemeier U, Pohlmann T (1997) Meteorological and oceanographic situation in the German Bight from 23 to 29 April 1991. Mar Ecol Prog Ser 156:263-273

Slomp CP, van Raaphorst W, Malschaert JFP, Kok A, Sandee AJJ (1993) The effect of deposition of organic matter on phosphorus dynamics in experimental marine sediment systems. Hydrobiologia 253:83-98

This article was submitted to the editor
Steiff B (1988) Fluctuation and significance of microzooplankton at Helgoland. Mitt Geol-Paläont Inst Univ Hamb 65: 423-437

Veldhuis MJW, Admiraal W, Colijn F (1986) Chemical and physiological changes of phytoplankton during the spring bloom, dominated by Phaeocystis pouchetii (Haptophyceae): observations in Dutch coastal waters of the North Sea. Neth J Sea Res 20:49-60

Veldhuis MJW, Venekamp LAH, letswaart I (1987) Availability of phosphorus sources for blooms of Phaeocystis pouchetii (Haptophyceae) in the North Sea: impact of the river Rhine. Neth J Sea Res 21:219-229

Manuscript received: January 2, 1997

Revised version accepted: June 2, 1997 